\title{
IMMIGRATION ENFORCEMENT, THE RACIALIZATION OF LEGAL STATUS, AND PERCEPTIONS OF THE POLICE
}

\section{Latinos in Chicago, Los Angeles, Houston, and Phoenix in Comparative Perspective}

\section{Cecilia Menjívar}

Department of Sociology, and Center for Migration Research, University of Kansas

\section{William Paul Simmons}

Gender \& Women's Studies, and Online Graduate Programs in Human Rights Practice, University of Arizona

\section{Daniel Alvord}

Department of Sociology, and Center for Migration Research, University of Kansas

\section{Elizabeth Salerno Valdez}

$\mathrm{Mel}$ and Enid Zuckerman College of Public Health, University of Arizona

\begin{abstract}
The immigration enforcement system today affects different subgroups of Latinos; it reaches beyond the undocumented to immigrants who hold legal statuses and even to the U.S.-born. States have enacted their own enforcement collaboration agreements with federal authorities and thus Latinos may have dissimilar experiences based on where they live. This article examines the effects of enforcement schemes on Latinos' likelihood of reporting crimes to police and views of law enforcement. It includes documented and U.S-born Latinos to capture the spillover beyond the undocumented, and it is based on four metropolitan areas-Los Angeles, Houston, Phoenix, and Chicago-to comparatively assess the effects of various enforcement contexts. Empirically, it relies on data from a random sample survey of over 2000 Latinos conducted in 2012 in these four cities. Results show that spillover effects vary by context and legal/citizenship status: Latino immigrants with legal status are less inclined to report to the police as compared to U.S.-born Latinos in Houston, Los Angeles, and Phoenix but not in Chicago. At the other end, the spillover effect in Phoenix is so strong that it almost reaches to U.S.-born Latinos. The spillover effect identified is possible due to the close association between
\end{abstract}

Du Bois Review, 15:1 (2018) 107-128.

(C) 2018 Hutchins Center for African and African American Research 1742-058X/18 \$15.00 doi:10.1017/S1742058X18000115 
being Latino or Mexican and being undocumented, underscoring the racialization of legal status and of immigration enforcement today.

Keywords: U.S.-Born Latinos, Latino Immigrants, Racialization, Immigration Enforcement, Citizenship Legal Status, Chicago, Los Angeles, Phoenix, Houston

\section{INTRODUCTION}

Changes in immigration law since the mid-1990s have conscripted local police forces into immigration enforcement. This development, and its twin process, the criminalizing of immigrants, particularly Latinos (Vázquez 2015), has impacted relations between immigrant and Latino communities and the police. With expanded deportation priorities under the new administration in Washington, which treats all unauthorized immigrants as subject to removal, and administrative efforts to expand certain agreements (e.g., Executive Order 13768), ${ }^{1}$ the comingling of policing and immigration enforcement is also being significantly expanded. This close collaboration between federal immigration enforcement and local authorities threatens the trust and cooperation between police and communities that is essential for law enforcement, and in doing so, compromises community policing efforts (Armenta 2017; Nguyen and Gill, 2016).

This turn toward "immigration federalism" (Motomura 1999) has marked a new era in state-level immigration enforcement. The importance of local police and sheriffs in immigration enforcement has been driven by a succession of different federal programs - namely the U.S. Immigration and Custom's Enforcement's (ICE) Agreements of Cooperation in Communities to Enhance Safety and Security (ACCESS) and specifically $287(\mathrm{~g})$. ACCESS and $287(\mathrm{~g})$ were provisions in the 1996 Illegal Immigration Reform and Immigrant Responsibility Act (IIRIRA) that gave local law enforcement the power to enforce immigration law voluntarily. ${ }^{2}$ After the passage of $287(\mathrm{~g})$, few police agencies participated (Coleman 2012) and the first department did not join until 2002 (Armenta and Alvarez, 2017). In 2008, ICE launched the Secure Communities program, which enhanced partnerships between federal, state, and local enforcement agencies through the creation of integrated databases across levels of government to identify undocumented immigrants for removal. Some of these programs, like $287(\mathrm{~g})$, are voluntary, and local agencies decide when to issue ICE detainers. Secure Communities was initially considered voluntary, but when local jurisdictions tried to opt out of the program they were informed that it was mandatory; by 2014 all jurisdictions in the United States were part of this program. However, this program was discontinued after several local law enforcement jurisdictions passed ordinances limiting their cooperation with immigration enforcement (American Immigration Council 2017). Secure Communities was replaced with the Priority Enforcement Program (PEP), ${ }^{3}$ which maintained many of the same mechanisms (e.g., every person who is booked into a jail has his or her fingerprints checked against an immigration database).

These policy changes endorse police as gatekeepers of immigration enforcement, giving them the discretion to decide whom to investigate and arrest (Motomura 2011). Use of such discretion creates the perception that police encounters can and will eventually lead to deportation (Coleman and Kocher, 2011). In this climate of dramatically increased deportations and expanded police involvement in immigration enforcement, community-police relations are threatened in two ways: 1) local officers' mistrust of immigrants is amplified as anyone who belongs to the targeted group (e.g., Latinos) can be a suspect; and 2) immigrants, whether documented (e.g., with legal status) or undocumented, become more distrustful of the police, often with major consequences 
for public safety. It is the latter aspect on which we focus. In a context of increasing and expanded collaborations between immigration enforcement and police work, we examine Latinos' willingness to report crimes across varying levels of such collaborations in four U.S. cities: Chicago, Houston, Los Angeles, and Phoenix.

In our examination, the dramatic increase in legislative activity at lower levels of government is central, particularly in its variation across states and municipalities. ${ }^{4}$ Although only the federal government can control who is admitted or how many immigrants are allowed into the country, states do control access to goods and benefits, and thus contribute to creating and reinforcing new forms of internal border control (Leerkes et al., 2013). Some state and municipal governments have embraced federal approaches to enforcement and have sought greater involvement in immigration enforcement while others have responded in the opposite direction (Varsanyi 2010). We now have a panoply of state laws and municipal ordinances that do not always comport, and sometimes even conflict, with federal enforcement initiatives (Aranda et al., 2014), as well as varying degrees and measures of enforcement at different geographic scales (see Walker and Leitner, 2011). For instance, in the first half of 2017, lawmakers in forty-seven states enacted 133 laws and 195 resolutions related to immigration (National Conference of State Legislatures 2017), many of which dealt with: legal identifications (IDs) or driver's licenses (some states restricting eligibility, others providing state-issued ID cards); extending or restricting access to higher education through in-state tuition requirements; and some (e.g., Georgia's H 452) changing definitions of domestic terrorism to facilitate enforcement collaboration with federal agencies. A common denominator in these laws is that they target practices and behaviors that are commonly associated with experiences of Latino immigrants; thus, this population has become the primary target of enforcement. Given the racialized implementation of laws, we posit that Latinos' willingness to report crimes will vary according to local levels of legislative activity that target this group.

Latinos make up the overwhelming majority of the immigrant population that is detained and deported in the United States. Tanya Golash-Boza and Pierrette Hondagneu-Sotelo (2013) observe that, "between 1993 and 2011 . . there was a 10-fold increase in the number of Mexican deportees, and a 12-fold increase in the number of Central American deportees" (p. 274). At the same time, the deportations of Asian and European immigrants increased fourfold and those of African and Caribbean immigrants only doubled (Golash-Boza and Hondagneu-Sotelo, 2013), with a mismatch between these enforcement numbers and the proportion of undocumented immigrants in those immigrant groups (Menjívar et al., 2016). These lopsided enforcement practices that target Latinos underscore the racialization embedded in them (Vaquera et al., 2014). They suggest an increasing reliance on legal status as a proxy for race (Møller 2014) and the centrality of racialization processes in immigration today (Kibria et al., 2013). As such, "illegality" is not a race-neutral term; it has become synonymous with "Mexicanness" or being Latino (Armenta and Vega, 2017; Chavez 2013; Provine et al., 2016) — an association with deep historical roots (see Escobar 1999; Ngai 2004). "Illegality," like race, has therefore become a central organizing axis of stratification (see Peterson and Krivo, 2010). As Douglas Massey (n.d.) observes, the race-based enforcement system today affects Latinos/as in similar ways as the criminal justice system has impacted Blacks (see also Bosworth, Parmar, and Vázquez 2018; Brotherton and Kretsedemas 2008).

Given the racialization of immigration enforcement today, undocumented Latino immigrants are not the only ones experiencing the effects of expanded enforcement. There has been a spillover effect (Aranda et al., 2014) that reaches to a wide swath of the Latino population regardless of generation (Ebert and Ovink, 2014), nativity 
(Donato and Rodriguez, 2014), or legal status (Szkupinski Quiroga et al., 2014). Although undocumented Latinos worry the most about deportation, research has found that $66 \%$ of Hispanic lawful permanent residents (e.g., those who hold a 'green card') and $33 \%$ of U.S.-born Hispanics worry about their own deportation or that of a family member (Pew Research Center 2017). ${ }^{5}$ Thus, Rogelio Sáenz and Maria Christina Morales (2015) found few differences in Latinos' perceptions of the police by citizenship or legal status. It is this spillover effect across legal and citizenship statuses that interests us because it points to the racialization of Latinos and of legal status under current enforcement practices, with effects on Latinos' relations with enforcement and police work more generally.

In this article, we examine Latinos' willingness to report crimes to the police. Following the major factors that may impinge on this outcome, delineated above and detailed below, we disaggregate Latinos by legal and citizenship status (undocumented immigrants, lawful permanent residents, and U.S.-born Latinos), and contexts (the four cities that we analyze) with varying degrees of enforcement. We tease out the effects of enforcement on the undocumented and on Latinos more generally so as to capture the spillover effect. As states and local contexts vary in enforcement intensity, and as Latinos bear the brunt of the enforcement system today and legal status for them is racialized and criminalized under the current enforcement regime, effects may vary by context (city).

\section{RACE AND VIEWS OF THE POLICE}

Yuning $\mathrm{Wu}$ and colleagues (2011) observe that, "Race has been one of the most important and consistent factors in shaping citizens' perceptions of the police" (p. 746). Thus, African Americans tend to have less positive views of the police than Whites (Decker 1985; Peck 2015; Tyler 2005; Weitzer and Tuch, 2006), but results are less consistent among other minority groups. Consequently, there have been calls to expand research on Latino perceptions of the police (Martinez 2007; Peterson and Krivo, 2005; Weitzer 2014) and immigrants' perceptions of the police (Wu 2010). We build on this research by focusing on Latinos in different citizenship and legal statuses, and adding the effects of immigration enforcement as this is increasingly shaping their experiences with law enforcement.

The scholarship on Latinos' and Asians' perceptions of the police generally places these groups somewhere between Whites and Blacks, with Arab Americans also holding generally positive views of the police (Sun and $\mathrm{Wu}, 2015$ ). For instance, $75 \%$ of Whites indicated in a Pew survey that they thought the police were doing an excellent job regarding use of force in their work; only $33 \%$ of Blacks shared this view, and $62 \%$ of Hispanics said that the police were doing at least a good job (Morin and Stepler, 2016). Such views mirror crime reporting statistics. In a survey conducted in California, White victims of sexual assault were twice as likely as Latinos to report crimes, and Whites and Asians were more likely than Latinos to report robberies (Rennison 2007). Jennifer Peck (2015) summarizes this work, "In certain studies, Hispanics tended to have more positive views of the police compared to Blacks, yet more negative attitudes than Whites" (p. 174; see also Vidales et al., 2009).

Notably, Latino perceptions of police have shifted over time. Earlier research found that Latinos and Whites held similarly positive views of police (Cheurprakobkit 2000; Ong and Jenks, 2004), but with increased negative contact with the criminal justice system (through expanded immigration enforcement) their views have shifted (Lopez and Livingston, 2009). And while not all Latinos are immigrants, the commingling of 
the racialization of legal status with increased immigration enforcement has enveloped all Latinos, immigrants and nonimmigrants alike. For instance, in certain contexts even native-born Latinos are being stopped and some are even deported (Heyman 2010; Provine et al., 2016; Sáenz and Morales, 2015). We build on this literature to assess whether immigration enforcement context creates conditions for Latinos to be less likely to report crimes in four cities with high concentrations of Latinos, but where the intensity of immigration enforcement varies.

\section{Immigrants' Views of the Police and Crime Reporting}

The scholarship on immigrants' trust in the police yields contradictory findings, particularly regarding geography. For instance, compared to nonimmigrants, Latino and Asian immigrants in Seattle held more positive views of the police (Davis and Hendricks, 2007). Chinese immigrants in three East Coast areas also rated police favorably (Wu et al., 2011). Similarly, Latino immigrants in Nevada held more favorable views of the police than nonimmigrants (Correia 2010), and high levels of trust in the police were found among Bangladeshi immigrants in New York (Khondaker et al., 2016). Africanborn immigrants view police more positively than do African Americans (Unnever and Gabbidon, 2013). However, in contrast to these studies, others have found that immigrants have more negative perceptions of the police than do the native born (Skogan et al., 2002). Chinese immigrants in New York, Philadelphia, and Delaware rate police lower than the native born do (Wu et al., 2011). Communities with large proportions of recently arrived immigrants also report lower evaluations of the police than their counterparts with smaller shares of recent immigrants (Davis and Mateu-Gelabert, 2000).

Most research combines ethnic and racial groups, but Asian and Latino immigrants are not homogenous groups; there are significant differences by nationality within these larger panethnic groups regarding views of the police (Menjívar and Bejarano, 2004; Wu 2014). For instance, Chinese immigrants have been found to have more positive views of the police than Vietnamese immigrants (Song 1992), while Cubans, Mexicans, and Central Americans have varied views of the police, depending on experiences with crime and the police in the country of origin (Menjívar and Bejarano, 2004; Wu et al., 2011). The current study compares mostly Mexican-origin individuals across citizenship and legal status given the close association between Mexicanness and undocumented status.

While the scholarship regarding perceptions of police among immigrants varies, there seems to be consensus in recent research that it is contact with the police that matters, not simply immigrant status. The importance of contact was noted by Wesley Skogan (2005), yet not in relation to immigration status. For some immigrants, contact with the police does not seem to impact police perceptions (Wu et al., 2012). However, Doris Chu and John Song (2008) found that Chinese immigrants in Toronto have negative views of police based on previous contact. For Latino immigrants, contact with police, and the nature of such contact, matters a great deal. This is likely related to the racialization and constructions of Latino immigrants as "illegal" (and criminal) (Menjívar and Kanstroom, 2014), which maps on to the shift in these immigrants' perceptions of police as having the dual role of protector and immigration enforcer (Armenta 2017), and the racism and discrimination they perceive (Vollmer Hanna and Ortega, 2016).

Studies have found that the types of encounters with police impact both immigrants' and natives' perceptions of the police; what sets immigrants' encounters with police apart is being asked questions (by police) about their immigration status. One study (Theodore 2013) of Latinos in four cities, found that $44 \%$ of respondents report 
being unwilling to contact police, with $70 \%$ of those being undocumented. But fear of police contact is not confined to immigrants when the ethnic group with whom they identify seems to be a target of police enforcement. Thus, $28 \%$ of U.S.-born Latinos indicate that they are less likely to contact police if victimized; since local law enforcement has become more involved in immigration enforcement, they fear that they will be asked about their immigration status (Theodore 2013). A 2014 Pew survey indicated that $46 \%$ of Latinos felt that police would treat them as fairly as they treat Whites, and $45 \%$ felt that local police work to gain the trust of the community (Krogstad 2014). However, Hispanics who are asked their immigration status by police have less confidence in the police compared to those who are not so questioned (Barrick 2014). In the end, encounters with police that involve questions about immigration status may contribute to a higher likelihood of not contacting police or reporting crimes (Theodore and Habans, 2016). Here, we examine how crime reporting is impacted when police are involved in varying degrees of federal immigration enforcement among Latinos who are native born, have legal status, and are undocumented.

Recent crime reporting trends show that after President Trump's Executive Orders, which involve a significant expansion in interior enforcement, reporting among Latinos, particularly among the undocumented, has decreased significantly more than among other ethnic groups (see Dart 2017). Since undocumented immigrants, especially Latinos, are the intended targets of enforcement, we focus on Latinos with legal status and U.S.-born Latinos to examine how even these (supposedly nontargeted) groups experience racialized enforcement, a practice that contributes to merging undocumented status with being Latino. The spillover effect to these other subgroups underscores the racialization of legal status for Latinos.

Immigrants' social positions and characteristics, such as age (Chow 2002; Davis and Hendricks, 2007) can also shape perceptions of police; however, not all research reports such effects (Correia 2010; Wu et al., 2011). Age interacts with contact with police and exposure to harsh police stops, but this is true for natives as well as first- and secondgeneration immigrants (Rengifo and Fratello, 2014). Latino/a youth, like their African American counterparts, view the police negatively and believe they are abusing their power (Solis et al., 2009). Also, experiences with police in immigrants' origin countries affect trust in the police in the United States (Menjivar and Bejarano, 2004; Wu et al., 2011); and, length of time residing in the U.S. also matters (Chow 2002; Chu and Hung, 2010). Examinations of language proficiency have produced mixed results (Chow 2002; Correia 2010). In this study we include the impact of age and language as predictors of crime reporting to assess whether the influence of these factors vary by context.

Geographic location also matters, but most of the research on trust and perceptions of police focuses on one city. Comparative studies across cities (Peck 2015; Taylor et al., 2001; Thomas and Burns, 2005; Wu 2010) have examined the Black/White divide or include Hispanics. However, very few examine the same group (holding different legal and citizenship statuses) across cities. We fill this gap by examining Latinos across four cities with varying immigration enforcement regimes.

The effect of gender on perceptions of the police varies across locations. For instance, Robert Davis and Nicole Hendricks (2007) studied Seattle residents and found that women are less satisfied with their contacts with police than men, while Mark Correia's (2010) analysis of Reno residents revealed that men have less favorable responses toward police than women. A national study of Latino/as by David Becerra and colleagues (2016) showed that Latinas are more likely than Latinos to report to police when they have been victims of crime, but are less likely to think that Latinos would be treated fairly by police. We control for gender in the analysis below, and consider how this factor varies across the four settings that we investigate. 
Fear of deportation has been identified as a significant predictor of Latinos' perceptions of the fairness of the criminal justice system (Becerra et al., 2016; Messing et al., 2015). Becerra and colleagues (2016) found that individuals with greater fear of deportation were significantly more likely to report: 1) less confidence that police would not use excessive force; 2) less confidence that police would treat Latinos fairly; 3) a lower likelihood of reporting violent crimes to police; and 4) less confidence that the courts would treat Latinos fairly. However, trust in the police is more important than fear of deportation in Latinos' willingness to report violent crime victimization (Becerra et al., 2016). Instead of directly looking at fear of deportation, we indirectly capture this effect through a question about whether a close friend or family member had been deported in the last two years.

Legal or citizenship status has largely been absent from previous analyses of immigrants' perceptions of police (Wu 2010). Yet in the few studies that have considered legal status, it plays an important role. For example, Mexican immigrants generally hold favorable views of the police, unless they came to the United States without inspection (Roles et al., 2016). We build on this scholarship by examining legal and citizenship status to demonstrate how Latinos as a group are racialized as undocumented in the context of immigration enforcement today.

Our data set allows us to examine the relationships discussed above and how they vary across four major metropolitan areas: Maricopa County, Arizona (Phoenix), Cook County, Illinois (Chicago), Los Angeles County, California (Los Angeles), and Harris County, Texas (Houston). These settings differ substantially in the extent to which local law enforcement collaborates with federal immigration enforcement which, we argue, affects the association of legal/citizenship status with reporting to the police.

\section{FOUR CONTEXTS IN COMPARATIVE PERSPECTIVE}

The discretionary power granted by programs such as $287(\mathrm{~g})$ and Secure Communities extends greater authority to local police (Coleman 2012), even as the "overwhelming majority" of local law enforcement agencies do not directly enforce immigration law (Armenta and Alvarez, 2017: 3). Thus, the enforcement of internal borders by local law enforcement agencies can vary dramatically by geography and jurisdiction (Coleman 2012; Armenta and Alvarez, 2017).

The partisan makeup of voters in immigrant destinations (Wong 2012), cities with Hispanic police chiefs (Provine et al., 2016), local sanctuary city ordinances (Ridgley 2008), the personal ideology of local sheriffs (Farris and Holman, 2016) and police chiefs (Coleman 2012) can all influence the relationship between local law enforcement and the federal immigration bureaucracy. For instance, local city police and county sheriffs interact differently with undocumented residents in their jurisdictions, with sheriffs being more likely to cooperate with immigration officials than local city police (Provine et al., 2016), apparently a result of the status of sheriffs as elected officials. Nonetheless, some local police incorporate immigration enforcement into their already existing routines and enforcement practices.

The immigration enforcement schemes in the four jurisdictions where the data for this study come from have received intensive scrutiny from the media, activists, and policymakers. For parsimony, we will at times refer to each of these jurisdictions by their largest city, even though our data and some of our discussions of local policies are countywide. These jurisdictions vary in geography, demographics, and political culture, so we should not be surprised that they vary substantially in how they involve local law enforcement in immigration enforcement. Chicago and Los Angeles are 
generally considered welcoming to immigrants, but Chicago has been implementing what can be considered "sanctuary" policies longer and more consistently. For Houston and Phoenix immigration enforcement has a prominent place in local law enforcement (Eagly 2013), ${ }^{6}$ again with important differences as Phoenix has been at the forefront nationally in immigration enforcement at the local level.

\section{Chicago (Cook County)}

Chicago (Cook County) became a sanctuary city in 1985 when authorities made it city policy not to ask individuals about their immigration status. This policy was reaffirmed and codified into city law in 2006. It prohibited city agencies from asking about the immigration status of people seeking city services or if individuals were victims or witnesses of crimes. Cook County was also the first U.S. county to ignore all ICE detainer requests, a vital part of the $287(\mathrm{~g})$ and Secure Communities programs. The County's Board of Commissioners passed an "immigration detainer ordinance" in September 2011 which declared that the County Sherriff's office would no longer abide by detainers requested by ICE. The move was touted as a cost savings measure, but commissioners were also concerned that "holding inmates for ICE violates due process rights and erodes community trust in local police" (Mitchell 2011). In 2017, faced with President Trump's plan to withhold federal dollars from "sanctuary cities," the Chicago City Council voted to remain a sanctuary city, pledging to challenge the president's policy in court if needed. The mayor also set up a legal defense fund to help undocumented immigrants targeted by the new Executive Orders. Initially the Chicago ordinance provided that in some cases, especially those involving gang members and those wanted on felony charges, the city's police would cooperate with ICE. However, under pressure from immigration rights activists, this policy was further clarified in 2016 to target only individuals involved in serious crimes. ${ }^{7}$

\section{Los Angeles (City and County)}

Like Chicago/Cook County, Los Angeles city and county are relatively speaking considered to be welcoming jurisdictions to immigrants. In 2013 the California assembly passed, and the governor signed, the TRUST Act, ${ }^{8}$ which prohibits local law enforcement from abiding by ICE detainer requests except in the case of serious crimes. Even then, local law enforcement has discretion in deciding whether to cooperate with hold requests. However, Los Angeles has been slower and less consistent than Chicago in adopting sanctuary policies. While in 1979 Los Angeles established Special Order 40, which prevents the Los Angeles Police Department from asking individuals their immigration status unless a crime has been committed, in 2005 this city began allowing federal immigration agents inside the county jails to check for immigration status, and county deputies to ask county inmates about their immigration status. Los Angeles County signed on to the Secure Communities program in 2009, only a year into the program. These policies were changed in 2015, when the County Board withdrew from the 287(g) program. However, at the same time Los Angeles County signed on to the Obama administration's Priority Enforcement Program (PEP) with the stipulation that the Sherriff only notify ICE of very serious crimes. More recently, in response to the Trump administration's Executive Orders, like Chicago, Los Angeles city and county have set up a legal defense fund for undocumented immigrants targeted by ICE. Ingrid Eagly (2013) labels Los Angeles an "alienage-neutral model" of immigration enforcement where actors throughout the criminal justice system do not inquire about immigration status, nor do they consider immigration status in adjudication (p. 1157). 


\section{Houston (Harris County)}

Houston/Harris County has consistently pursued tough immigration enforcement policies. At the beginning of 2017, Harris County was one of only two Texas counties and one of only thirty-two jurisdictions nationally still participating in the 287(g) program, with deputies interviewing inmates about their immigration status. This policy had been met with intense criticism and protests, but the County Board and Sheriff remained adamantly committed to the program. The $287(\mathrm{~g})$ agreement was finally terminated in February 2017 upon the election of a new county sheriff. The Secure Communities program was piloted in Harris County in 2008 (Eagly 2013). Indeed, immigration status plays a big role throughout the criminal justice system. "Harris County treats illegal alien defendants more punitively-with respect to bail eligibility, plea bargaining, and sentencing-compared with the rest of the criminal defendant population" (Eagly 2013, p. 1170). However, unlike Phoenix, Houston has been consistent in not allowing law enforcement officials to ask about immigration status in the course of policing on the streets.

\section{Phoenix (Maricopa County)}

Phoenix/Maricopa County, especially under the Maricopa County Sheriff's Office (MCSO), has perhaps been the most notorious anti-immigrant jurisdiction in the United States. The MCSO has been marked by widespread human rights abuses and discrimination against the Latino population, which has faced xenophobic rhetoric and lived under expanded enforcement (some might argue, siege) for years.

Maricopa County was an early (and eager) adopter of the $287(\mathrm{~g})$ program and the Secure Communities program. What distinguishes the Phoenix area is the implementation of additional laws and policies that affect immigration enforcement. For instance, the state of Arizona passed an anti-smuggling law in 2005, and under a bizarre interpretation (later found to be unconstitutional), the then Maricopa County Attorney prosecuted immigrants for conspiring to smuggle themselves. Further, Arizona voters approved Proposition 100, which denied bail to undocumented immigrants accused of felonious crimes (redefined to include anyone who had smuggled themselves), and Proposition 102, which barred undocumented immigrants from collecting punitive damages in civil lawsuits. Another state law required law enforcement to ask anyone placed in jail for their immigration status. MCSO set up checkpoints throughout the county, actions later ruled unconstitutional because they amounted to the racial profiling of Latinos. Using the Legal Arizona Workers' Act (LAWA) of 2008, MCSO conducted workplace raids (or 'identity theft' investigations as MCSO referred to them) in search of undocumented immigrants working with borrowed or fake documents. These investigations relied on Arizona's identity theft law, which is broader in reach than federal law. Homeland Security Secretary Napolitano issued a memo in December 2011 stopping MCSO's participation in 287(g) and the Secure Communities program due to "findings of discriminatory policing practices."

In April 2010, SB 1070 was passed, though it was never fully implemented. This bill contained several provisions aimed not only at identifying undocumented immigrants to authorities, but also at encouraging these immigrants to leave the state, via the "attrition through enforcement" approach. The best-known measure contained in this bill was the "show me your papers" provision, which required law enforcement agents to determine the legal status of an individual during a lawful encounter. In 2012, the U.S. Supreme Court ruled that most of its provisions were unconstitutional. However, the "show your papers" provision was left in place, which requires law enforcement officials to determine the legal status of anyone arrested or detained 
if there is "reasonable suspicion" that the person is in the country undocumented.9 Due to the office's approach to enforcing this provision, MCSO faced multiple lawsuits and was ordered to stop these practices as they were found to amount to racial profiling.

In brief, the four different city/county approaches to immigration enforcement described above may have had serious consequences with regard to detentions, deportations, and their related activities and consequences. For example, Eagly (2013), who studied three of the four jurisdictions we examine, reports that "in Maricopa County only $42 \%$ of individuals screened through Secure Communities and later deported had felonies or multiple misdemeanors" while "Los Angeles has the largest percentage of deportations of serious Level 1 offenders" and about half the number of "deportations that result from low-grade misdemeanors (Level 3 )" in comparison to Houston and Phoenix (p. 1214). Given such disparities in the participation of local police in immigration enforcement across the four metropolitan areas we study, we hope to shed light on how enforcement practices affect Latinos' likelihood of reporting crimes. Examining crime reporting is important; it reflects levels of trust in and views of the police, and also plays a role in solving crimes, and thereby addressing victimization (reporting on crimes observed or experienced is often the first step in solving a crime).

Based on the extant scholarship and the policies of the four jurisdictions, we hypothesize that:

$\mathrm{H}_{1}$ : Negative contacts with the police and knowing someone who has been deported in the past two years will be negatively related to Police Reporting.

$\mathrm{H}_{2}$ : Being undocumented will be negatively related to Police Reporting, and there will be some spillover effect to immigrants with legal status, especially in counties with stricter immigration enforcement.

$\mathrm{H}_{3}$ : Latinos in jurisdictions where local law enforcement has been more heavily involved in immigration enforcement will score lower on Police Reporting.

\section{DATA AND METHODS}

\section{Data}

This study is based on a telephone survey conducted by Lake Research Partners in November and December of 2012, using a random digit dialing sample that focused on heavily Latino census tracts. The respondents included approximately 500 Latinos from each of four large metropolitan counties: Cook (Chicago), Harris (Houston), Los Angeles, and Maricopa (Phoenix) $(\mathrm{n}=2004) .{ }^{10}$ Note that after listwise deletion of missing cases the sample size was reduced from 2004 to 1524 . Almost three quarters of the interviews were conducted in Spanish (for more information on the methodology see Theodore 2013). Approximately thirty-five questions were asked that measured perceptions of immigration enforcement by local agencies as well as respondents' experiences with local law enforcement.

\section{The Dependent Variable}

The survey asked eleven specific questions about reactions to local law enforcement officials becoming more involved with immigration enforcement. Three of these were used to create a scale of Police Reporting that serves as our dependent variable. Using a Likert 
type scale, respondents were asked to indicate their reactions to local law enforcement officials becoming more involved with immigration enforcement, including their likelihood of: contacting police officers if they were a victim of crime because they would be asked about their immigration status; voluntarily offering information to police about crimes about which they were aware; and, reporting a crime to law enforcement officers. Scores on these three questions were averaged to create the scale of Police Reporting. The reliability of the scale was quite good (Cronbach's Alpha $=.833) .{ }^{11}$

\section{Independent Variables}

Drawing on recent literature on immigration enforcement, our analysis of police reporting includes several important independent variables capturing: city/county context; immigration status; deportation experiences; and the nature of interactions with the police. For our analysis, we created several dummy variables to capture city/ county context Los Angeles, Houston, and Phoenix, with Chicago (where police have been the least involved with federal immigration enforcement) as the reference category. Dummy variables were also constructed to distinguish between individuals who are undocumented, immigrants with status, or Latinos born in the United States (reference category). To measure experiences with deportation, we created a dummy variable, deported, which distinguishes respondents who have had one or more family members or friends deported in the previous two years from those who have not. Finally, negative interactions with police are based on responses to eleven questions such as: whether, in the past year, the respondent or his/her friends or family members had been stopped by police officers or other law enforcement officials; the respondent had been asked for his/her immigration papers; the respondent had been threatened with deportation; and, the respondent had been insulted or verbally disrespected by officers. A summative scale was created for respondents' personal negative experiences with law enforcement officials as a count of the number of such experiences reported (range 0-11). On average, respondents reported 2.2 negative incidents with a police officer or other law enforcement official involving themselves in their city in the previous year.

\section{Control Variables}

A variety of additional variables that have been found to be associated with police reporting are controlled in the analyses. Most of the controls are operationalized as dummy variables; the exceptions are age and education. Specifically the control variables are: female; Mexico (whether respondents are of Mexican origin or not); kids (whether or not a respondent has children under eighteen years of age); employment (a dummy variable where 1 means employed full-time or part-time and 0 means not employed); Spanish (whether the interview was conducted only in Spanish); age (an ordinal variable grouped in five year increments); and, education (coded as less than high school =1, high school graduate $=2$, and beyond high school $=3$ ).

\section{Descriptive Statistics}

Table 1 reports the frequencies of the variables included in our analysis. A majority $(56 \%)$ of the respondents were women and $45 \%$ had children under the age of eighteen. The respondents ranged from age eighteen to ninety-two; $42 \%$ did not have a high school education, and 53\% were employed either fulltime or part-time. Almost $80 \%$ of the survey respondents reported that their family originated from Mexico, and $73 \%$ were interviewed in Spanish. 
Cecilia Menjívar et al.

Table 1. Frequencies and Percentages of Variables in the Analysis

\begin{tabular}{|c|c|c|c|}
\hline Variable & Value & Frequency & Percentage \\
\hline \multirow[t]{4}{*}{ Location } & Chicago & 349 & $22.9 \%$ \\
\hline & Los Angeles & 376 & 24.7 \\
\hline & Houston & 390 & 25.6 \\
\hline & Phoenix & 409 & 26.8 \\
\hline \multirow[t]{3}{*}{ Immigration Status } & Born in US & 432 & 28.4 \\
\hline & Immigrant with Status & 810 & 53.2 \\
\hline & Undocumented & 282 & 18.5 \\
\hline \multirow{4}{*}{$\begin{array}{l}\text { Have any close friends or } \\
\text { family members been } \\
\text { deported in past two years }\end{array}$} & Both Family and Friends & 298 & 19.5 \\
\hline & Family Members & 184 & 12.1 \\
\hline & Friends & 114 & 7.5 \\
\hline & No One & 1042 & 68.4 \\
\hline \multirow[t]{2}{*}{ Female } & No & 670 & 44.0 \\
\hline & Yes & 854 & 56.0 \\
\hline \multirow[t]{2}{*}{ Spanish Language Interview } & No & 412 & 27.0 \\
\hline & Yes & 1110 & 72.8 \\
\hline \multirow[t]{2}{*}{ Employed } & Not Employed & 712 & 46.7 \\
\hline & Part Time or Full Time & 812 & 53.3 \\
\hline \multirow[t]{3}{*}{ Education } & Up to $11^{\text {th }}$ Grade & 632 & 41.5 \\
\hline & High School Graduate & 476 & 31.2 \\
\hline & Beyond High School & 416 & 27.3 \\
\hline \multirow[t]{2}{*}{ Mexico } & Non-Mexican Origin & 310 & 20.3 \\
\hline & Mexican Origin & 1214 & 79.7 \\
\hline \multirow[t]{2}{*}{ Kids (Under 18) } & No & 832 & 54.6 \\
\hline & Yes & 692 & 45.4 \\
\hline \multirow{4}{*}{$\begin{array}{l}\text { Less Likely to Contact } \\
\text { if Victim of Crime }\end{array}$} & Strongly Disagree & 545 & 35.8 \\
\hline & Somewhat Disagree & 278 & 18.2 \\
\hline & Somewhat Agree & 303 & 19.9 \\
\hline & Strongly Agree & 398 & 26.1 \\
\hline \multirow{4}{*}{$\begin{array}{l}\text { Less Likely to Voluntarily } \\
\text { Offer Information }\end{array}$} & Strongly Disagree & 523 & 34.3 \\
\hline & Somewhat Disagree & 284 & 18.6 \\
\hline & Somewhat Agree & 317 & 20.8 \\
\hline & Strongly Agree & 400 & 26.3 \\
\hline \multirow{4}{*}{$\begin{array}{l}\text { Less Likely to Report } \\
\text { a Crime }\end{array}$} & Strongly Disagree & 541 & 35.5 \\
\hline & Somewhat Disagree & 282 & 18.5 \\
\hline & Somewhat Agree & 325 & 21.3 \\
\hline & Strongly Agree & 376 & 24.7 \\
\hline
\end{tabular}

A large number of individuals in the sample were less willing to interact with the police: $46 \%$ reported (strongly agree and somewhat agree) that they were less likely to contact police officers if they were a victim of crime because they would be asked about their immigration status; $47 \%$ were less likely to voluntarily offer information about crimes; and $46 \%$ were less likely to report a crime to law enforcement officers. Regarding the independent variables, nearly equal proportions of respondents resided 
in each of the four cities (from $23 \%$ to $27 \%$ ). Additionally, $19 \%$ of the respondents selfreported not being in the United States legally, 28\% were born in the United States, while $53 \%$ were immigrants with legal status. ${ }^{12}$ Additionally, $32 \%$ of the respondents reported that at least one of their close friends or family members had been deported in the previous two years. Finally, approximately $20 \%$ of the sample reported having experienced at least three negative incidents in their interactions with law enforcement officers over the past year, and $25 \%$ reported that friends or family members had experienced at least three such negative incidents over the past year (negative incident figures not shown in table).

While our analysis relies only on the variables mentioned above, the following information is helpful for setting the current work in a broader understanding of the experiences of this sample. Many survey respondents reported being affected by immigration enforcement policies, including the involvement of local law enforcement. Almost all the respondents (94\%) reported either an increase in involvement by local law enforcement in immigration enforcement (44\%) or no change (50\%). More than half of survey participants reported that they had friends who were undocumented, and almost $40 \%$ had relatives who were undocumented. We did not include the following variables in the ensuing analysis. Perceived increase in law enforcement due to its ambiguity. ${ }^{13}$ Nor did we include having undocumented friends or family because of the high correlation with the respondent being undocumented $(r=.470, p=.000)$. In a separate paper, we analyze the predictors of social isolation; here, it is important to note that many respondents reported being more socially isolated due to the involvement of local law enforcement in immigration enforcement. Significantly, 39\% of the respondents reported being afraid to leave the house because of local law enforcement's involvement in immigration enforcement activities and 44\% felt more isolated while 39\% felt under more suspicion.

\section{RESULTS}

With our dependent variable, the police reporting scale, we ran Ordinary Least Squares (OLS) regression analyses for the entire sample and for each city. Table 2 reports regression results for the entire sample using listwise deletion of cases for missing data. As a reminder, city and legal status are categorical variables coded as a set of dummies; Chicago and born in the United States are the respective reference categories. Phoenix is the only significant city variable, with those in Phoenix significantly less likely than Chicago residents to contact the police even after controlling for all the other variables. As expected, those with more negative interactions with the police and who have friends or family who were deported in the previous two years are also significantly less likely to be willing to report to the police. Undocumented immigrants, but importantly, also documented immigrants (e.g., with legal status) are significantly less willing to contact the police than their U.S.-born counterparts, even when controlling for knowing someone who was deported and negative encounters with law enforcement. We would expect those who are undocumented to be less likely to want any police contact through reporting, but these findings indicate a spillover effect reaching beyond the targeted group (e.g., undocumented) to other subgroups of Latinos, including those who have legal status. ${ }^{14}$ Latino immigrants who are documented may fear for their families as they are likely to live with undocumented relatives than are U.S.-born Latinos, but importantly, in a context of racialized legal status, immigration enforcement has targeted them along with the undocumented. Moreover, to compound this situation further, there are thousands of lawful permanent residents also being deported (American Immigration Council 2010; Meissner et al., 2013). 
Cecilia Menjívar et al.

Table 2. OLS Regression Predicting Reporting to Police (Entire Sample)

\begin{tabular}{lrrrr}
\hline \hline Variable & \multicolumn{1}{c}{ b } & Beta & t & Sig. \\
\hline Los Angeles & .064 & .026 & .922 & .357 \\
Phoenix & -.144 & -.061 & -2.082 & .037 \\
Houston & -.015 & -.006 & -.218 & .827 \\
Immigrant with Status & -.321 & -.153 & -4.712 & .000 \\
Undocumented & -.800 & -.297 & -9.290 & .000 \\
Negative Interactions with the Police & -.068 & -.163 & -5.989 & .000 \\
Deported Friends or Family & -.211 & -.141 & -5.149 & .000 \\
Female & -.084 & -.040 & -1.695 & .090 \\
Mexico & -.028 & -.011 & -.455 & .649 \\
Kids & .064 & .030 & 1.200 & .230 \\
Employment & .035 & .017 & .666 & .506 \\
Spanish & -.255 & -.109 & -3.836 & .000 \\
Age & .020 & .059 & 2.375 & .018 \\
Education & .087 & .068 & 2.608 & .009 \\
(Constant) & 3.088 & & 22.844 & .000 \\
$\mathrm{R}^{2}$ & .221 & & & \\
p & .000 & & & \\
$\mathrm{~N}$ & 1524 & & & \\
\hline \hline
\end{tabular}

In contrast to other research (see Becerra et al., 2016), gender is not significant here; however, other demographic variables, such as conducting the interview in Spanish, age, and education are significant. As expected, individuals who were interviewed in Spanish were less willing to report to the police, owing to the likelihood that their monolingual language ability would trigger questions about legal status in a context that equates Mexicanness (or being Latino) with undocumented legal status. Older respondents and those with more education are more willing to report to the police.

Since immigration enforcement schemes are quite different in the four jurisdictions in our study, it is appropriate to run separate regression equations for each city. This is further confirmed by the bivariate correlations (available from the authors), which show that the underlying factors correlated with willingness to contact police differ between the jurisdictions. The OLS regression results for the four cities are shown in Table 3.

As expected, the OLS equations show different significant variables for each city. Negative interactions with the police are significant in each city except Chicago, while knowing someone who was deported in the previous two years is significant in all cities except Los Angeles. This may be due to the sanctuary city status of some of these cities (or at least an intention of becoming one or being relatively more welcoming) described earlier. Thus, even having more negative interactions with police in Chicago or knowing someone who has been deported in Los Angeles is not significantly associated with less willingness to report to police.

As for immigration status, there is a significant spillover effect to immigrants with documentation/legal status in Los Angeles, Houston, and Phoenix, but not in Chicago. Chicago's sanctuary policies may be having the effect of promoting interactions with the police, especially for immigrants with status. Interestingly, the difference between the U.S.-born and documented immigrants is just barely significant $(p=.044)$ in the 
Table 3. OLS Regression Predicting Reporting to Police (by Jurisdiction)

\begin{tabular}{|c|c|c|c|c|c|c|c|c|}
\hline \multirow[b]{2}{*}{ Variable } & \multicolumn{2}{|c|}{ Chicago } & \multicolumn{2}{|c|}{ Los Angeles } & \multicolumn{2}{|c|}{ Houston } & \multicolumn{2}{|c|}{ Phoenix } \\
\hline & b (t-score) & Beta & b (t-score) & Beta & b (t-score) & Beta & b (t-score) & Beta \\
\hline $\begin{array}{l}\text { Immigrant } \\
\text { with Status }\end{array}$ & $\begin{array}{l}-.203 \\
(-1.384)\end{array}$ & -.101 & $\begin{array}{l}-.534^{* *} \\
(-3.442)\end{array}$ & -.253 & $\begin{array}{l}-.339^{* *} \\
(-2.880)\end{array}$ & -.162 & $\begin{array}{l}-.274^{*} \\
(-2.021)\end{array}$ & -.128 \\
\hline Undocumented & $\begin{array}{l}-.719^{* *} \\
(-3.702)\end{array}$ & -.258 & $\begin{array}{l}-1.003^{* *} \\
(-5.545)\end{array}$ & -.392 & $\begin{array}{l}-.939^{* *} \\
(-5.839)\end{array}$ & -.359 & $\begin{array}{l}-.628^{* *} \\
(-3.742)\end{array}$ & -.224 \\
\hline $\begin{array}{l}\text { Negative } \\
\text { Interactions } \\
\text { with the Police }\end{array}$ & $\begin{array}{c}-.044 \\
(-1.699)\end{array}$ & -.103 & $\begin{array}{l}-.079^{* *} \\
(-2.754)\end{array}$ & -.144 & $\begin{array}{l}-.082^{* *} \\
(-3.929)\end{array}$ & -.214 & $\begin{array}{l}-.063^{* *} \\
(-3.247)\end{array}$ & -.168 \\
\hline Deported & $\begin{array}{l}-.291^{* *} \\
(-3.071)\end{array}$ & -.180 & $\begin{array}{l}-.047 \\
(-.539)\end{array}$ & -.029 & $\begin{array}{l}-.222^{* *} \\
(-2.865)\end{array}$ & -.162 & $\begin{array}{l}-.241^{* *} \\
(-3.246)\end{array}$ & -.166 \\
\hline Female & $\begin{array}{l}-.069 \\
(-.667)\end{array}$ & -.034 & $\begin{array}{l}.026 \\
(.245)\end{array}$ & .012 & $\begin{array}{l}-.033 \\
(-.360)\end{array}$ & -.016 & $\begin{array}{c}-.212^{*} \\
(-2.093)\end{array}$ & -.099 \\
\hline Mexico & $\begin{array}{l}.208 \\
(1.717)\end{array}$ & .089 & $\begin{array}{l}.079 \\
(.680)\end{array}$ & .033 & $\begin{array}{l}-.162 \\
(-1.474)\end{array}$ & -.063 & $\begin{array}{l}-.385^{\star} \\
(-2.533)\end{array}$ & -.113 \\
\hline Kids & $\begin{array}{l}.011 \\
(.097)\end{array}$ & .005 & $\begin{array}{l}-.091 \\
(-.797)\end{array}$ & -.043 & $\begin{array}{l}.327^{* *} \\
(3.401)\end{array}$ & .156 & $\begin{array}{l}.013 \\
(.118)\end{array}$ & .006 \\
\hline Employment & $\begin{array}{c}-.129 \\
(-1.115)\end{array}$ & -.064 & $\begin{array}{l}.153 \\
(1.403)\end{array}$ & .073 & $\begin{array}{l}-.073 \\
(-.718)\end{array}$ & -.035 & $\begin{array}{l}.152 \\
(1.492)\end{array}$ & .071 \\
\hline Spanish & $\begin{array}{l}-.087 \\
(.626)\end{array}$ & -.038 & $\begin{array}{l}-.223 \\
(-1.618)\end{array}$ & -.092 & $\begin{array}{l}-.325^{\text {** }} \\
(-2.659)\end{array}$ & -.129 & $\begin{array}{l}-.358^{* *} \\
(-2.624)\end{array}$ & -.160 \\
\hline Age & $\begin{array}{l}.006 \\
(.309)\end{array}$ & .018 & $\begin{array}{l}.030 \\
(1.640)\end{array}$ & .090 & $\begin{array}{l}.025 \\
(1.670)\end{array}$ & .076 & $\begin{array}{l}.014 \\
(.851)\end{array}$ & .041 \\
\hline Education & $\begin{array}{l}.246^{* *} \\
(3.515)\end{array}$ & .200 & $\begin{array}{l}-.055 \\
(-.778)\end{array}$ & -.043 & $\begin{array}{l}.157^{*} \\
(2.489)\end{array}$ & .121 & $\begin{array}{l}.020 \\
(.300)\end{array}$ & .015 \\
\hline \multirow[t]{4}{*}{ (Constant) } & $\begin{array}{l}2.415^{* *} \\
(9.149)\end{array}$ & & $\begin{array}{l}1.701^{* *} \\
(6.693)\end{array}$ & & $\begin{array}{l}1.953^{* *} \\
(8.235)\end{array}$ & & $\begin{array}{l}1.520^{* *} \\
(5.733)\end{array}$ & \\
\hline & \multicolumn{2}{|c|}{$\mathrm{R}^{2}=.187$} & \multicolumn{2}{|c|}{$\mathrm{R}^{2}=.182$} & \multicolumn{2}{|c|}{$\mathrm{R}^{2}=.343$} & \multicolumn{2}{|c|}{$\mathrm{R}^{2}=.241$} \\
\hline & \multicolumn{2}{|c|}{$\mathrm{p}=.000$} & \multicolumn{2}{|c|}{$\mathrm{p}=.000$} & \multicolumn{2}{|c|}{$\mathrm{p}=.000$} & \multicolumn{2}{|c|}{$\mathrm{p}=.000$} \\
\hline & \multicolumn{2}{|c|}{$\mathrm{N}=348$} & \multicolumn{2}{|c|}{$\mathrm{N}=375$} & \multicolumn{2}{|c|}{$\mathrm{N}=389$} & \multicolumn{2}{|c|}{$\mathrm{N}=408$} \\
\hline
\end{tabular}

$*=\mathrm{p}<.05$

$* *=\mathrm{p}<.01$

Phoenix case. The unstandardized regression coefficients for undocumented individuals and immigrants with status are smaller in Phoenix than in the other three cities. This suggests that the policies in Phoenix are producing the greatest similarities in the likelihood of police reporting of the native-born with immigrants (whether documented or not). This may be due to greater reluctance of the (Latino) native-born to report to the police than is the case in the other cities.

Gender is significant in Phoenix but not in the other three jurisdictions. Women are significantly less likely to be willing to report to the police in Phoenix. This may be due to fears among women, as the socially designated caretakers of their families, about family separation through deportation, in the context of strict anti-immigrant policies and ramped up enforcement. Among other demographic variables, education is significant in Chicago, with those who have more education being more willing to report to police. In Los Angeles, none of the demographic variables are significant. 
In Houston, on the other hand, those who have kids and those with more education are more likely to report to the police, while those who speak Spanish are less likely to do so. In Phoenix, being from Mexico and speaking Spanish puts people in a position to be less likely to report to the police.

\section{DISCUSSION/CONCLUSION}

The Lake Research Partners' survey used here of over 2000 Latinos with various legal and citizenship statuses allowed us to examine comparatively their likelihood of reporting crimes to the police across four large jurisdictions with different immigration enforcement schemes. Overall, Latinos in these cities are primed to be suspicious of law enforcement. Approximately half of the respondents reported an unwillingness to contact the police, even if they were victims of crime, because they or other people they knew could be asked about their immigration status. Further, our first hypothesis was supported for the whole sample and for three of the four cities. Those who have friends or family who were deported within the previous two years, or who had more negative interactions with police in the past year, were significantly less likely to be willing to report crimes to the police. Sanctuary policies in Chicago and Los Angeles seem to be having the desired effect. Negative interactions with the police in Chicago and knowing someone who was deported in Los Angeles are not significantly related to police reporting. Also, in Chicago and Los Angeles, speaking Spanish, which in a racialized enforcement atmosphere would mark someone as potentially deportable, was not significantly related to willingness to report to the police.

In line with our second hypothesis and other scholarship (Sáenz and Morales, 2015), we found a significant spillover effect that reaches to different subgroups of Latinos among our whole sample, with Latino immigrants with legal status being significantly less likely to report to the police as compared to U.S.-born Latinos. This may be related to the increase in deportations of lawful permanent residents, which moves these immigrants closer to the undocumented in terms of legal insecurity, affecting their contacts with the police. Noteworthy, spillover effects vary across immigration enforcement schemes context. There is no spillover effect among Latino immigrants with legal status in Chicago, but there is in the other three jurisdictions. Indeed, the spillover effect in Phoenix/Maricopa County almost reaches to U.S.-born Latinos, perhaps due to the severity of enforcement and racial profiling in that county. In addition, speaking Spanish, a marker for potential deportability in a racialized atmosphere (e.g., associated with being Latino), is significant in both Phoenix and Houston. Finally, gender is significant in Phoenix but not in the other three cities. Women in Phoenix are less likely to be willing to report to the police, not surprising in the context with the strictest anti-immigrant policies. Even though women are detained and deported less frequently than men, they likely fear separation from their families, given their socially-designated role as main caretakers in their families.

Our study reveals that in the current immigration enforcement context, which relies heavily on the racializing legal status that equates "Mexicanness" or Latinos with "illegality," legal status becomes an important lens for understanding discrimination and exclusion in society. As Massey and Karen Pren (2012) observe, although Latinos are a protected category under U.S. law, undocumented migrants are not. Thus, legal status, in contrast to other forms of stratification, permits (sometimes even requires) formal discriminatory treatment of certain groups, evident in practices of enforcement and control. The racial profiling of Latinos is intertwined with the expanded enforcement that targets this group in particular, regardless of their documentation/legal status. 
As such, the spillover effect reaches to a wide swath of the Latino population beyond the undocumented, and it is made possible because "Mexicanness" (and Latino identity) has been closely associated with an undocumented status (Armenta and Vega, 2017; Chavez 2013; Provine et al., 2016). Even speaking Spanish (associated with being Latino) triggers this spillover effect. But as with other axes of stratification, these effects are experienced intersectionally by context and likely by gender, among other social positions.

From the foregoing discussion, policy choices are clear. The United States is currently involved in a battle between the current administration in Washington, which is championing many of the harshest anti-enforcement policies that were present in Phoenix/Maricopa County, and numerous state and local jurisdictions that are advocating for the types of sanctuary policies that Chicago has had in place for years. Recent research finds that crime rates are lower in counties with sanctuary policies or that there is no statistically significant association between the two (Wong 2018). Thus, in contrast to the vitriolic rhetoric coming from many in the media and government, as shown in our analysis, sanctuary city policies promote community policing work and very likely contribute to safer communities.

Corresponding author: Cecilia Menjívar, Department of Sociology, University of Kansas, 716 Fraser Hall, Lawrence, KS 66045. E-mail: menjivar@ku.edu.

\section{NOTES}

1. Signed on January 25, 2017, Executive Order 13768, "Enhancing Public Safety in the Interior of the United States:" prioritizes all undocumented immigrants for removal (the Obama administration prioritized certain individuals with prior records), and focuses on removing immigrants from the interior of the country (in contrast to returning or removing them from border areas); expands the involvement of state and local police in immigration enforcement; authorizes the hiring of additional Immigration and Custom's Enforcement (ICE) agents; puts pressure on countries to accept their deported nationals; and creates the Office for Victims of Immigrant Crimes, among other provisions.

2. We would like to note the tensions that arise between federal authorities and sheriffs' offices as each seeks to abide by their goals https://www.nytimes.com/2017/09/13/us/sheriffsimmigration-enforcement-jails.html (accessed April 23, 2018)

3. The Priority Enforcement Program (PEP), established in 2014, is an ICE program that further expanded collaboration between federal and state and local law enforcement. The program was set to prioritize 'criminal offenders,' that is, immigrants who were previously deported and have returned to the country and are therefore now classified as felons, along with immigrants who have committed an aggravated felony. The program, therefore, further fused immigrants who have crossed the border with those who have committed a crime. However, the Executive orders that the new president signed in January 2017 no longer prioritize immigrants according to their supposed criminality; these orders have expanded the category of criminality by including immigrants suspected of committing a crime as well as undocumented presence itself.

4. A common explanation for the increased legislative activity at lower levels of government is that state legislators have grown frustrated with the federal government's lack of will to 'fix' the 'broken immigration system,' or that the federal government 'is not doing enough.' But as Møller (2014) observes, the federal government has already significantly intensified its own enforcement strategies through multiplying border and interior enforcement strategies as well as human power, as well as expanding budgets, detention centers, and surveillance.

5. We use the term Hispanic in this paper when we refer to research on Latinos/Hispanics that have utilized this term. Otherwise, we use the term Latino.

6. Our ranking is supported by Eagly's (2013) fine-toothed "on-the-ground" inquiry about the links between criminal procedures and immigration in Houston, Los Angeles, and Phoenix. 
7. Our results for Chicago/Cook County should not be interpreted as an absence of racialization and racism in that context; the institutionalized racism that Van Cleve (2016) observed in the same county should be kept in mind.

8. As of this writing, California passed SB 54, which effectively makes California a sanctuary state.

9. By 2016, Arizona's SB 1070 had lost most of its power, but other states are now attempting to pass similar laws under the guise of punishing "Sanctuary Cities" for not complying with federal law. As of this writing, Texas's SB 4, which exemplifies this trend, is being debated.

10. The respondents were screened to ensure that they identified as Latino or Hispanic. Note, the original data set and the frequencies reported using that data set by Theodore and Habans (2016) were weighted so that there were 501 respondents from each county. We use unweighted data for the reported frequencies and all subsequent analyses.

11. The remaining questions focused on whether increased involvement in immigration enforcement by local police led respondents to feeling safer or less safe, being afraid to leave the house, or feeling isolated.

12. For a comparison, the composition of the U.S. foreign-born population is as follows: $41.8 \%$ are naturalized citizens, $27.4 \%$ are lawful permanent residents, $4.5 \%$ have a temporary or discretionary status, and $24.3 \%$ are undocumented (Waters and Gerstein-Pineau, 2016).

13. The "no change" response is ambiguous as this question asked whether there was a change in local law enforcement involvement in the previous two years (recall the survey was conducted in late 2012) while the $287(\mathrm{~g})$ program and other initiatives had been active for several years prior, and Houston, and especially Phoenix, had been eagerly involved.

14. Research from Los Angeles examining Latinos' experiences of discrimination (Landale et al., 2017) has found that undocumented immigrants do not report particularly high levels of discrimination, but U.S.-born young Latinos report the most mistreatment in personal and institutional domains. These contrasting results to ours may be due to the timing of data collection (2006-2008 vs. ours in 2012), as enforcement has become more intense in recent years.

\section{REFERENCES}

American Immigration Council (2010). The Ones They Leave Behind: Deportation of Lawful Permanent Residents Harms U.S. Citizens <https://www.americanimmigrationcouncil.org/ sites/default/files/research/Childs_Best_Interest_Fact_Sheet_042610.pdf> (accessed April 23, 2018).

American Immigration Council (2017). The 287(g) Program: An Overview. March 15. <https:// www.americanimmigrationcouncil.org/research/287g-program-immigration $>$ (accessed June 2, 2017).

Aranda, Elizabeth, Cecilia Menjívar, and Katharine M. Donato (2014). The Spillover Consequences of an Enforcement-First U.S. Immigration Regime. American Bebavioral Scientist, 58(13): $1687-1695$.

Armenta, Amada (2017). Protect, Serve, and Deport: The Rise of Policing as Immigration Enforcement. Oakland, CA: University of California Press.

Armenta, Amada, and Isabela Alvarez (2017). Policing Immigrants or Policing Immigration? Understanding Local Law Enforcement Participation in Immigration Control. Sociology Compass, 11(2): https://doi.org/10.1111/soc4.12453.

Armenta, Amada, and Irene I. Vega (2017). Latinos in the Crimmigration System. In Mathieu Deflem (Ed.), Race, Ethnicity and Law (Sociology of Crime, Law and Deviance, Volume 22), pp. 221-236. West Yorkshire, UK: Emerald Publishing Limited.

Barrick, Kelle (2014). Latino Confidence in the Police: The Role of Immigration Enforcement, Assimilation, and Immigration Status. Fournal of Ethnicity in Criminal Fustice, 12(4): 289-307.

Becerra, David, M. Alex Wagaman, David Androff, Jill Messing, and Jason Castillo (2016). Policing Immigrants: Fear of Deportations and Perceptions of Law Enforcement and Criminal Justice. Fournal of Social Work, 17 (6): 715-731. https://doi.org/10.1177/1468017316651995.

Bosworth, Mary, Alpa Parmar, and Yolanda Vázquez (Eds.). 2018. Race, Criminal Justice, and Migration Control: Enforcing the Boundaries of Belonging. New York, NY: Oxford University Press.

Brotherton, David C., and Philip Kretsedemas. 2008. Keeping Out the Other: A Critical Introduction to Immigration Enforcement Today. New York, NY: Columbia University Press. 
Chavez, Leo R. (2013). The Latino Threat: Constructing Immigrants, Citizens, and the Nation. Stanford, CA: Stanford University Press.

Cheurprakobkit, Sutham (2000). Police-citizen Contact and Police Performance: Attitudinal Differences between Hispanics and Non-Hispanics. Fournal of Criminal Fustice, 28(4): 325-336.

Chow, Henry P. H. (2002). Police-community Relations: Chinese Attitudes toward the Police in Toronto. Canadian Ethnic Studies, 34(2): 90-101.

Chu, Doris C., and John Huey-Long Song (2008). Chinese Immigrants' Perceptions of the Police in Toronto, Canada. Policing: An International fournal of Police Strategies and Management, 31(4): 610-630.

Chu, Doris C., and Linda S. J. Hung (2010). Chinese Immigrants' Attitudes toward the Police In San Francisco. Policing: An International Fournal of Police Strategies and Management, 33(4): 621-643.

Coleman, Mathew (2012). The "Local" Migration State: The Site-Specific Devolution of Immigration Enforcement in the U.S. South. Law and Policy, 34(2): 159-190.

Coleman, Mathew, and Austin Kocher (2011). Detention, Deportation, Devolution and Immigrant Incapacitation in the US, Post 9/11. The Geographical fournal, 177(3): 228-237.

Correia, Mark E. (2010). Determinants of Attitudes toward Police of Latino Immigrants and Non-Immigrants. Fournal of Criminal fustice, 38(1): 99-107.

Dart, Tom (2017). Fearing Deportation, Undocumented Immigrants Wary of Reporting Crimes. $<$ https://www.theguardian.com/us-news/2017/mar/23/undocumented-immigrants-waryreport-crimes-deportation> (accessed June 2, 2017).

Davis, Robert C., and Nicole J. Hendricks (2007). Immigrants and Law Enforcement: A Comparison of Native-Born and Foreign-Born Americans' Opinions of the Police. International Review of Victimology, 14(1): 81-94.

Davis, Robert C., and Pedro Mateu-Gelabert (2000). Effective Police Management Affects Citizen Perceptions, National Institute of fustice fournal, July: 24-25.

Decker, Scott H. (1985). The Police and the Public: Perceptions and Policy Recommendation. In Robert J. Homant, and Daniel B. Kennedy (Eds.), Police and Law Enforcement, 1975-1981, pp. 89-105. New York: AMS Press.

Donato, Katharine M., and Leslie Rodriguez (2014). Police Arrests in a Time of Uncertainty: The Impact of $287(\mathrm{~g})$ on Arrests in a New Immigrant Gateway. American Behavioral Scientist, 58(13): 1696-1722.

Eagly, Ingrid V. (2013). Criminal Justice for Non-Citizens: An Analysis of Variation in Local Enforcement. New York University Law Review, 88: 1126-1223.

Ebert, Kim, and Sarah Ovink (2014). Exclusionary Ordinances and Discrimination in New and Established Latino/a Destinations. American Behavioral Scientist, 58(13): 1784-1804.

Escobar, Edward J. (1999). Race, Police, and the Making of a Political Identity: Mexican Americans and the Los Angeles Police Department, 1900-1945. Berkeley, CA: University of California Press.

Farris, Emily M., and Mirya R. Holman (2016). All Politics Is Local? County Sheriffs and Localized Policies of Immigration Enforcement. Political Research Quarterly, 70(1): 142-154.

Golash-Boza, Tanya, and Pierrette Hondagneu-Sotelo (2013). Latino Immigrant Men and the Deportation Crisis: A Gendered Racial Removal Program. Latino Studies, 11(3): 271-292.

Heyman, Josiah (2010). Human Rights and Social Justice Briefing 1: Arizona's Immigration Law - SB 1070. Society for Applied Anthropology. <https://www.sfaa.net/files/8413/9570/4717/ HRSJIssueBriefing1.pdf> (accessed June 2, 2017).

Khondaker, Mahfuzul I., Yuning Wu, and Eric G. Lambert (2016). The Views of Bangladeshi Immigrants on the Police In New York City. Fournal of Crime and fustice, 39(4): 528-549.

Kibria, Nazli, Cara Bowman, and Megan O'Leary (2013). Race and Immigration. Cambridge, UK: Polity Press.

Krogstad, Jens Manuel (2014). Latino Confidence in Local Police Lower than Among Whites. Pew Research Center, August 28. <http://www.pewresearch.org/fact-tank/2014/08/28/latinoconfidence-in-local-police-lower-than-among-whites/> (accessed May 30, 2017).

Landale, Nancy S., R. S. Oropesa, and Aggie J. Noah (2017). Experiencing Discrimination in Los Angeles: Latinos at the Intersection of Legal Status and Socioeconomic Status. Social Science Research, 67: 34-48. https://doi.org/10.1016/j.ssresearch.2017.05.003.

Leerkes, Arjen, James D. Bachmeier, and Mark A. Leach (2013). When the Border is "Everywhere": State-level Variation in Migration Control and Changing Settlement Patterns of the Unauthorized Immigrant Population in the United States. International Migration Review, 47(4): 910-943.

Lopez, Mark Hugo, and Gretchen Livingston (2009). Hispanics and the Criminal Justice System: Low Confidence, High Exposure. Washington, DC: Pew Research Center <http://www. pewhispanic.org/files/reports/106.pdf> (accessed June 2, 2017). 
Martinez, Ramiro Jr. (2007). Incorporating Latinos and Immigrants into Policing Research. Criminology and Public Policy, 6(1): 57-64.

Massey, Douglas S. (no date). The New Latino Underclass: Immigration Enforcement as a Race-Making Institution. Stanford University: The Stanford Center on Poverty and Inequality. $<$ https://web.stanford.edu/group/scspi/_media/working_papers/massey_new-latino-underclass. pdf.> (accessed June 1, 2017).

Massey, Douglas S., and Karen A. Pren (2012). Origins of the New Latino Underclass. Race and Social Problems, 4(1): 5-17.

Meissner, Doris, Donald M. Kerwin, Muzaffar Chishti, and Claire Bergeron. 2013. Immigration Enforcement in the United States: The Rise of a Formidable Machine. Washington, DC: Migration Policy Institute.

Menjívar, Cecilia, and Cynthia Bejarano (2004). Latino Immigrants' Perceptions of Crime and Police Authorities in the United States: A Case Study from the Phoenix Metropolitan Area. Ethnic and Racial Studies, 27(1): 120-148.

Menjívar, Cecilia, and Daniel Kanstroom (Eds.) (2014). Constructing Immigrant 'Illegality': Critiques, Experiences, and Responses. New York: Cambridge University Press.

Menjívar, Cecilia, Leisy J. Abrego, and Leah C. Schmalzbauer (2016). Immigrant Families. Malden, MA: Polity Press.

Messing, Jill Theresa, David Beccera, Allison Ward-Lasher, and David K. Androff (2015). Latinas' Perceptions of Law Enforcement. Affilia, 30(3): 328-340.

Mitchell, Chip (2011). Illinois County Defies Feds On Immigrant Detentions. National Public Radio, September 12. <http://www.npr.org/2011/09/12/140407306/cook-county-ill-bucksimmigration-enforcement> (accessed June 2, 2017).

Møller, Pia (2014). Restoring Law and (Racial) Order to the Old Dominion: White Dreams and New Federalism in Anti-Immigrant Legislation. Cultural Studies, 28(5-6): 869-910.

Morin, Rich, and Renee Stepler (2016). The Racial Confidence Gap in Police Performance. Pew Research Center. <http://www.pewsocialtrends.org/2016/09/29/the-racial-confidencegap-in-police-performance/> (accessed May 30, 2017).

Motomura, Hiroshi (1999). Federalism, International Human Rights, and Immigration Exceptionalism. University of Colorado Law Review, 70: 1361-1394.

Motomura, Hiroshi (2011). The Discretion That Matters: Federal Immigration Enforcement, State and Local Arrests, and The Civil-Criminal Line. UCLA Law Review, 58: 1819-1858.

National Conference of State Legislatures (2017). Report on 2017 State Immigration Laws/ January-June. <http://www.ncsl.org/research/immigration/report-on-2017-state-immigrationlaws-january-june.aspx $>$ (accessed August 30, 2017).

Ngai, Mae M. 2004. Impossible Subjects: Illegal Aliens and the Making of Modern America. Princeton, NJ: Princeton University Press

Nguyen, Mai T., and Hannah Gill (2016). Interior Immigration Enforcement: The Impacts of Expanding Local Law Enforcement Authority. Urban Studies, 53(2): 302-323.

Ong, Marcos, and David A. Jenks (2004). Hispanic Perceptions of Community Policing. Fournal of Ethnicity in Criminal fustice, 2(3): 53-66.

Peck, Jennifer H. (2015). Minority Perceptions of the Police: A State-of-the-Art Review. Policing: An International Fournal of Police Strategies and Management, 38(1): 173-203.

Peterson, Ruth D., and Lauren J. Krivo (2005). Macrostructural Analyses of Race, Ethnicity, and Violent Crime: Recent Lessons and New Directions for Research. Annual Review of Sociology, 31: 331-356.

Peterson, Ruth D., and Lauren J. Krivo (2010). Divergent Social Worlds: Neighborhood Crime and the Racial-Spatial Divide. New York: Russell Sage.

Pew Research Center (2017). Latinos and the New Trump Administration. <http://www. pewhispanic.org/2017/02/23/latinos-and-the-new-trump-administration/> (accessed May 30, 2017).

Provine, Doris Marie, Monica Varsanyi, Paul G. Lewis, and Scott H. Decker. (2016). Policing Immigrants: Local Law Enforcement on the Front Lines. Chicago, IL: University of Chicago Press.

Rengifo, Andres F., and Jennifer Fratello (2014). Perceptions of the Police by Immigrant Youth: Looking at Stop-and-Frisk and Beyond Using a New York City Sample. Youth, Violence and Fuvenile Fustice, 13(4): 409-427.

Rennison, Callie M. (2007). Reporting to the Police by Latino Victims of Violence. Violence and Victims, 22(6): 754-772.

Ridgley, Jennifer (2008). Cities of Refuge: Immigration Enforcement, Police, and the Insurgent Genealogies of Citizenship in U.S. Sanctuary Cities. Urban Geography, 29(1): 53-77. 
Roles, Rocio, Stacy C. Moak, and Tusty ten Bensel (2016). Perceptions of Police Among Hispanic Immigrants of Mexican Origin in the Southeast United States. American fournal of Criminal fustice, 41(2): 202-219.

Sáenz, Rogelio, and Maria Christina Morales (2015). Latinos in the United States: Diversity and Change. Malden, MA: Polity Press.

Skogan, Wesley G. (2005). Citizen Satisfaction with Police Encounters. Police Quarterly, 8(2): $298-321$.

Skogan, Wesley G., Lynn Steiner, Jill DuBois, J. Erik Gudell, and Aimee Fagan (2002). Community Policing and 'The New Immigrants': Latinos in Chicago. Washington, DC: U.S. Department of Justice, Office of Justice Programs <https://www.ncjrs.gov/pdffiles1/ nij/189908.pdf> (accessed Jun 2, 2017).

Solis, Carmen, Edwardo L. Portillos, and Rod K. Brunson (2009). Latino Youths' Experiences with and Perceptions of Involuntary Police Encounters. The ANNALS of the American Academy of Political and Social Science, 623(1): 39-51.

Song, John Huey-Long (1992). Attitudes of Chinese Immigrants and Vietnamese Refugees towards Law Enforcement in the United States. Fustice Quarterly, 9(4): 703-719.

Sun, Ivan Y., and Yuning Wu (2015). Arab Americans' Confidence in Police. Crime and Delinquency, 61(4): 483-508.

Szkupinski, Quiroga, Dulce M. Medina Seline, and Jennifer Glick (2014). In the Belly of the Beast: Effects of Anti-Immigration Policy on Latino Community Members. American Behavioral Scientist, 58(3): 1723-1742.

Taylor, Terrance J., K. B. Turner, Finn-Aage Esbensen, and L. Thomas Winfree (2001). Coppin' an Attitude: Attitudinal Differences among Juveniles Toward Police. Fournal of Criminal fustice, 29(4): 295-305.

Theodore, Nik (2013). Insecure Communities: Latino Perceptions of Police Involvement in Immigration Enforcement. <https://greatcities.uic.edu/wp-content/uploads/2014/05/Insecure_Communities_ Report_FINAL.pdf (accessed June 2, 2017).

Theodore, Nik, and Robert Habans (2016). Policing Immigrant Communities: Latino Perceptions of Police Involvement in Immigration Enforcement. Fournal of Ethnic and Migration Studies, 42(6): 970-988.

Thomas, Matthew O., and Peter F. Burns (2005). Repairing the Divide: An Investigation of Community Policing and Citizen Attitudes Towards the Police by Race and Ethnicity. Fournal of Ethnicity in Criminal fustice, 3(1-2): 71-89.

Tyler, Tom R. (2005). Policing in Black and White: Ethnic Group Differences in Trust and Confidence in the Police. Police Quarterly, 8(3): 322-342.

Unnever, James D., and Shaun L. Gabbidon (2013). Do Blacks Speak with one Voice?: Immigrants, Public Opinions, and Perceptions of Criminal Injustices. Fustice Quarterly, 32(4): 680-704.

Van Cleve, Nicole Gonzalez (2016). Crook County: Racism and Injustice in America's Largest Criminal Court. Stanford, CA: Stanford University Press.

Vaquera, Elizabeth, Elizabeth Aranda, and Roberto Gonzalez (2014). Patterns of Incorporation of Latinos in Old and New Destinations. American Behavioral Scientist, 58(14): 1823-1833.

Varsanyi, Monica (2010). Taking Local Control: Immigration Policy Activism in U.S. Cities and States. Stanford, CA: Stanford University Press.

Vázquez, Yolanda (2015). Constructing Crimmigration: Latino Subordination in a "Post-Racial" World. Obio State Law fournal, 76: 599-657.

Vidales, Guadalupe, Kristen M. Day, and Michael Powe (2009). Police and Immigration Enforcement: Impacts on Latino(a) Residents' Perceptions of Police. Policing: An International fournal of Police Strategies and Management, 32(4): 631-653.

Vollmer Hanna, Ashley-Marie, and Debra Marie Ortega (2016). Salir Adelante (Perseverance): Lessons from the Mexican Immigrant Experience. Fournal of Social Work, 16(1): 47-65.

Walker, Kyle E. and Helga Leitner (2011). The Variegated Landscape of Local Immigration Policies in the United States. Urban Geography, 32(2): 156-178.

Waters, Mary C., and Marisa Gernstein-Pineau (Eds.) (2016). The Integration of Immigrants into American Society. Washington, DC: National Academies of Sciences, Engineering, and Medicine.

Weitzer, Ronald (2014). The Puzzling Neglect of Hispanic Americans in Research on PoliceCitizen Relations. Ethnic and Racial Studies, 37(11): 1995-2013.

Weitzer, Ronald, and Steven A. Tuch (2006). Race and Policing in America: Conflict and Reform. New York: Cambridge University Press.

Wong, Tom K. (2012). 287(g) and the Politics of Interior Immigration Control in the United States: Explaining Local Cooperation with Federal Immigration Authorities. Fournal of Ethnic and Migration Studies, 38(5): 737-756. 
Cecilia Menjívar et al.

Wong, Tom. K. (2018). "Sanctuary Cities Don't 'Breed Crime.' They Encourage People to Report Crime.” The Washington Post. https://www.washingtonpost.com/news/monkeycage/wp/2018/04/24/sanctuary-cities-dont-breed-crime-they-encourage-people-to-reportcrime/?utm_term=.fdd0fd254ac4 (accessed April 24, 2018).

Wu, Yuning (2010). Immigrants' Perceptions of the Police. Sociology Compass, 4(11): 924-935.

Wu, Yuning (2014). Race/Ethnicity and Perceptions of the Police: A Comparison of White, Black, Asian and Hispanic Americans. Policing and Society, 24(2): 135-157.

Wu, Yuning, Ivan Y. Sun, and Brad W. Smith (2011). Race, Immigration, and Policing: Chinese Immigrants' Satisfaction with Police. Fustice Quarterly, 28(5): 745-774.

Wu, Yuning, Ruth Triplett, and Ivan Y. Sun (2012). Chinese Immigrants' Contact with Police. Policing: An International fournal of Police Strategies and Management, 35(4): 741-760. 